\title{
PEMBUATAN MASKER WATERPROOF BERBAHAN POLYESTER UNTUK MENCEGAH PENULARAN DROPLET BAKTERI DAN VIRUS DALAM UPAYA PEMUTUSAN MATA RANTAI PENULARAN COVID-19
}

\author{
Seprianto, Molani Paulina Hasibuan, Ratih Permana Sari \\ Program Studi Pendidikan Kimia, Universitas Samudra \\ molanipaulinahsb@unsam.ac.id
}

\begin{abstract}
The Covid-19 pandemic has plagued almost all parts of the world. The virus is transmitted by droplets, droplets, or in medical terms known as droplets when someone coughs, sneezes, or talks. There are two ways of sharing the coronavirus through droplets, namely directly and indirectly. The use of masks in preventing direct transmission of the virus is an important thing to do. Making waterproof masks made from waterproof polyester fabrics, splash, or droplet seepage is an alternative for people to get proper masks without spending a lot of money. A waterproof mask made from a polyester cloth is more economical and more environmentally friendly because it can be reused. The simple manufacturing process and easy and inexpensive materials allow this business to be accepted by the community. This waterproof mask-making training can improve the people of Langsa City people, especially Lhokbanie Village, to face the Covid-19 pandemic. The mask products produced from this training can also be used repeatedly to protect the environment.
\end{abstract}

Keywords: Covid-19, Mask, Waterproof

\begin{abstract}
Abstrak
Pandemi Covid-19 sudah mewabah di hampir seluruh belahan dunia. Virus ditularkan melalui percikan, tetesan, atau dalam istilah medis dikenal sebagai droplet saat seseorang batuk, bersin, atau berbicara. Ada dua cara penularan virus corona melalui droplet yaitu secara langsung dan tidak langsung. Penggunaan masker dalam mencegah penularan virus secara langsung merupakan hal penting yang harus dilakukan. Pembuatan masker waterproof berbahan kain polyester yang anti air, percikan atau rembesan droplet merupakan salah satu alternative bagi masyarakat untuk memperoleh masker yang layak tanpa harus mengeluakan biaya yang banyak. Pemakaian masker waterproof berbahan kain polyester ini selain lebih hemat, juga lebih ramah lingkungan karena bisa dipakai ulang. Proses pembuatan yang sederhana dan bahan mudah dan murah memungkinkan usaha ini bisa diterima masyarakat. Pelatihan pembuatan masker waterproof ini dapat meningkatkan kesiapan masyarakat Kota Langsa, khususnya Gampong Lhokbanie dalam menghadapi pandemi Covid-19. Produk masker yang dihasilkan dari pelatihan ini juga dapat dipakai berulang sehingga dapat menjaga kelestarian lingkungan.
\end{abstract}

Kata kunci: Covid-19, Masker, Waterproof

MARTABE : Jurnal Pengabdian Masyarakat| 235 


\section{PENDAHULUAN}

Fenomena pneumonia jenis baru yang sekarang marak disebut dengan Covid-19 merupakan jenis penyakit yang disebabkan oleh corona virus (CoV) yang awalnya muncul pada desember 2019 di Wuhan, Cina. Dugaan awal hal ini terkait dengan pasar basah yang menjual ikan, hewan laut dan berbagai hewan lain. Pada 10 Januari 2020 penyebabnya mulai teridentifikasi dan didapatkan kode genetiknya yaitu virus corona baru (Handayani, dkk, 2020).

Covid-19 ini merupakan bagian dari keluarga corona virus yang juga menyebabkan penyakit yang sebelumnya sudah pernah muncul yaitu Mers-CoV dan Sars-CoV yang memiliki kesamaan menyerang system pernapasan. Namun penyebaran jenis Covid-19 ini berbeda dari pendahulunya karena bisa menyebar dari manusia ke manusia sehingga penyebarannya sangat cepat (Zhou). Gejala yang ditimbulkan Covid-19 ini mirip dengan pneumonia yaitu gejala flu seperti batuk, demam, letih, sesak napas, dan tidak nafsu makan. Namun akibat yang ditimbulkannya lebih parah karena perkembangan virusnya sangat cepat. Orang dengan penyakit bawaan atau riwayat gangguan kesehatan akan lebih rentan terhadap keparahan yang ditimbulkan Covid-19 ini (Mona,2020).

Virus corona menyebar secara contagious. Istilah contagion mengacu pada infeksi yang menyebar secara cepat dalam sebuah jaringan. Virus corona menunjukkan tingkat transmisi lebih tinggi daripada SARS dikarenakan terjadinya rekombinasi genetik yang telah meningkatkan kemampuan transmisi. Kelelawar dapat menginfeksi manusia melalui konsumsi danging kelelawar yang terinfeksi oleh coronavirus. Menurut data yang didapatkan melalui wawancara kepada pasien yang terinfeksi, sebanyak 55\% pernah melakukan kontak di pasar seafood yang ada dikota Wuhan, dimana tempat tersebut diduga menjadi awal penyebaran virus corona (Nugroho, 2020).

Covid-19 merupakan penyakit yang baru ditemukan sehingga pengetahuan terkait pencegahannya masih terbatas. Penemuan vaksin masih belum tersedia sehingga untuk pencegahannya dapat dilakukan dengan pemutusan rantai penularan dengan isolasi, deteksi dini, dan melakukan proteksi dasar. Beberapa hal yang dapat dilakukan adalah membudayakan higienis, cuci tangan, desinfeksi, penyediaan alat pelindung diri dan pemakaian masker ( Susilo A, dkk, 2020)

\section{METODE PELAKSANAAN}

Berdasarkan permasalahan prioritas yang dihadapi mitra dan hasil kesepakatn antara tim pengusul dengan mitra maka ditawarkan solusi sebagai berikut: Solusi yang ditawarkan adalah pembuatan masker waterproof berbahan polyester yang merupakan salah satu alternative bagi masyarakat untuk memperoleh masker layak pakai tanpa harus mengeluakan biaya yang banyak. Bahan ini banyak ditemukan di lingkungan masyarakat. Jika masyarakat sudah bisa membuat masker waterproof ini dengan mandiri, selain untuk pemakaian sendiri, bisa juga dibuat menjadi usaha produksi masker waterproof sehingga ekonomi masyarakat pun diharapkan bisa lebih baik. Lokasi kegiatan yang akan menjadi tempat pelaksanaan kegiatan adalah Desa Lhok Banie. Sasarannya adalah kelompok ibu-ibu PKK desa.

Output kegiatan PKM terdiri atas produk masker waterproof 
berbahan kain polyester yang dapat menahan droplet virus sehingga diharapakan dapat mengurangi bahkan mencegah penularan Covid-19. Sementara outcome yang diharapkan adalah peningkatan taraf pencegahan masyarakat terhadap penularan Covid19 dengan membudayakan pemakaian masker yang layak walaupun bukan masker medis, yaitu masker kain waterproof yang berpotensi untuk menangkal droplet virus sehingga pencegahan penularan dapat dimaksimalkan.

Prosedur kerja untuk mendukung realisasi metode yang ditawarkan kepada mitra dapat dilihat pada Gambar 1.

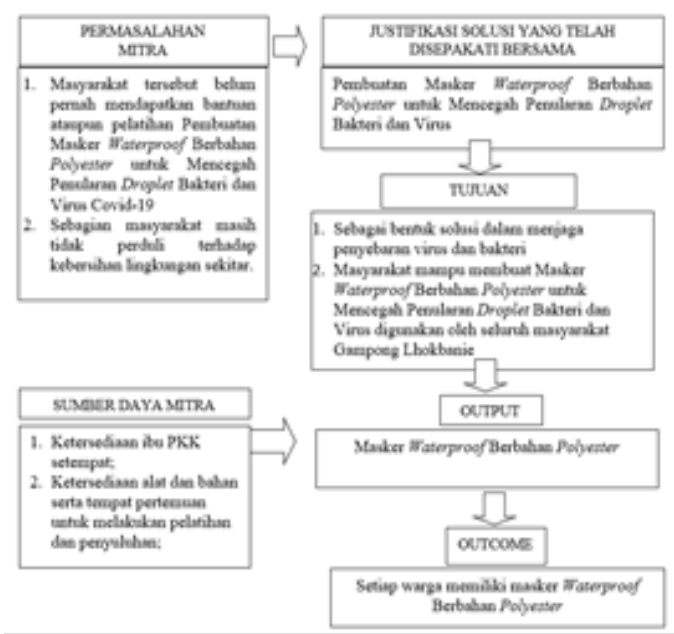

Gambar 1. Bagan Prosedur Kerja Realisasi Metode yang Ditawarkan

Langkah awal yang akan dilakukan adalah tim dosen bekerjasama dengan mahasiswa meminta izin pelaksanaan kegiatan kepada Geuchik Lhok Banie. Setelah memperoleh izin, tim dosen bekerjasama dengan mahasiswa memberikan penyuluhan kepada kelompok Ibu PKK tentang cara pembuatan masker waterproof, mulai dari penyediaan bahan hingga proses pembuatan produk.

Tim dosen akan memberikan penyuluhan dan bimbingan secara lengkap tentang proses pembuatan sabun antiseptik. Evaluasi akan dilakukan sekali dalam seminggu. Pengawasan yang lebih intens pada saat proses pembuatan dimaksudkan untuk menghasilkan produk yang benar-benar berkualitas baik.

\section{HASIL DAN PEMBAHASAN}

Melalui pengabdian yang dilakukan, masyarakat sudah memiliki keterampilan sesuai kegiatan yang telah dilatih, yaitu membuat masker waterproof sendiri sehingga bisa digunakan dalam berkegiatan di luar rumah tanpa harus membeli masker medis yang baik melindungi namun sekali pakai, ataupun masker kain (non medis) yang bisa dipakai berulangulang namun tidak bisa melindungi dengan baik dari penyebaran virus.

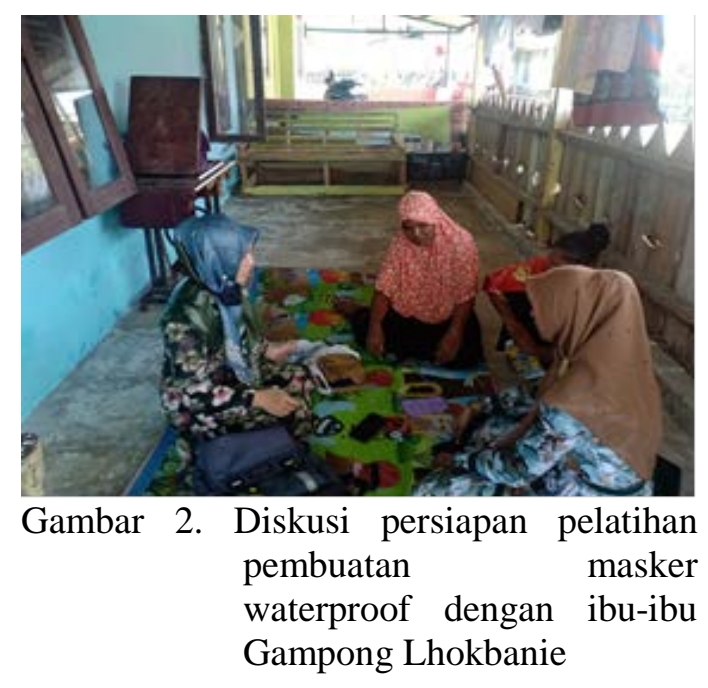

Kondisi mitra pada saat pelaksanaan pengabdian, yaitu ibu-ibu masyarakat Gampong Lhokbanie, diberikan pengarahan mengenai fenomena pandemic Covid-19, bahaya yang bisa ditimbulkan, serta cara pencegahan penularannya. Pelaksanaan pengabdian pada hari pertama terfokus pada penyampaian kegiatan-kegiatan yang bisa dilakukan dalam mencegah 
penyebaran Covid-19 di masyarakat. Salah satunya adalah dengan memproduksi masker yang memenuhi standar untuk bisa melindungi dari penyebaran droplet virus khususnya Covid-19. Masyarakat bisa membuat sendiri masker waterproof anti droplet virus sehingga tidak harus membeli maskler medis yang hanya bisa sekali pakai, ataupun masker non media (kain) yang bisa dipakai berulang-ulang namun kurang bisa melindungi dengan baik dari droplet virus. Setelah diberikan penyuluhan tentang pentingnya pemakaian masker, tim pengabdi mendiskusikan persiapan untuk kegiatan pelatihan "Pembuatan Masker Waterproof Berbahan Polyester untuk Mencegah Penularan Droplet Bakteri dan Virus" dengan ibu-ibu Gampong Lhokbanie. Proses pelaksanaan kegiatan dapat dilihat pada Gambar 2.

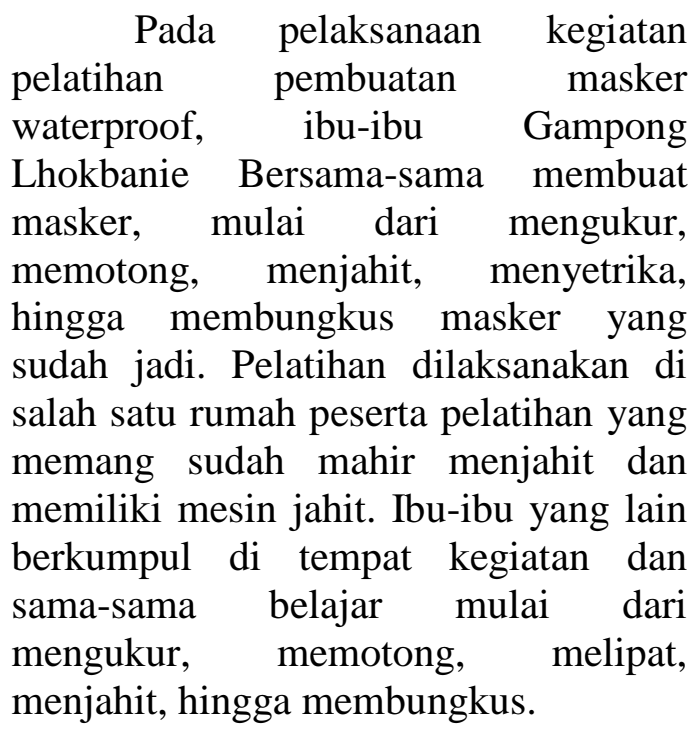

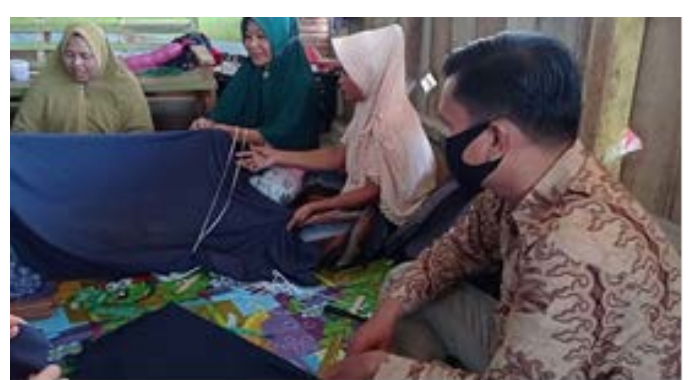

Gambar 3. Pengukuran bahan masker oleh ibu-ibu Gampong Lhokbanie

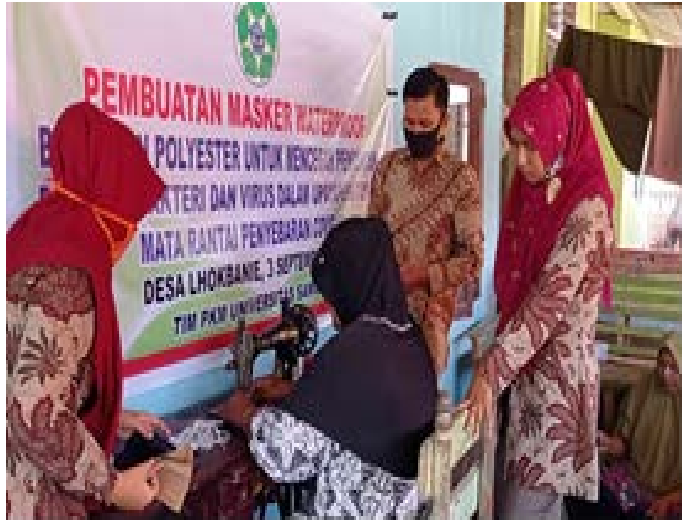

Gambar 4. Proses menjahit masker oleh ibu-ibu Gampong Lhokbanie

Kain yang digunakan adalah kain polyester dan kain cotton. Hal ini bertujuan untuk mencegah droplet virus bisa menyebar karena memiliki bagian yang anti air (waterproof) berupa kain polyester yang tahan air atau cairan, dan mencegah kepanasan di bagian dalam dengan menggunakan kain cotton yang lembut dan menyerap. Bentuk masker dibuat berlipat-lipat dan dikaitkan dengan karet kain.

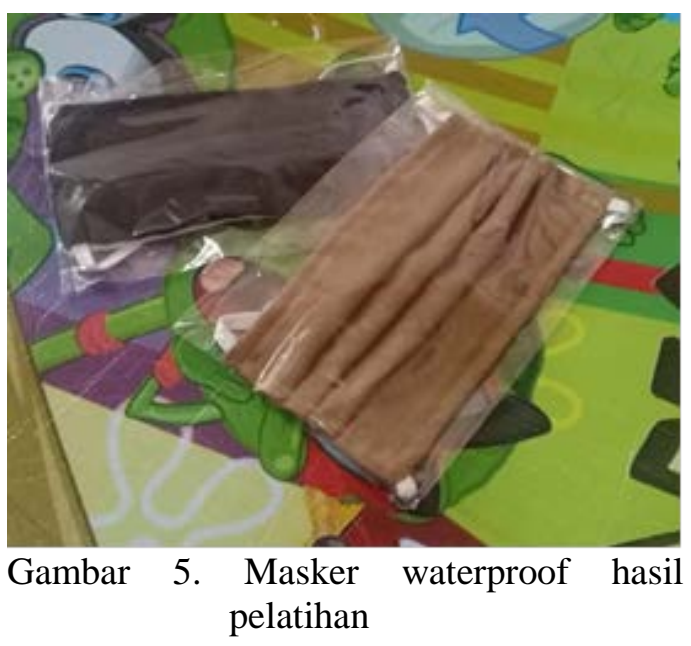

Hasil masker yang sudah jadi dibagi-bagikan kepada masyarakat. Pembagian masker dilakukan oleh tim pengabdi di beberapa titik di Gampong Lhokbanie, di antaranya di musholla gampong, di warung-warung sekitar gampong, dan ke beberapa rumah masyarakat. 


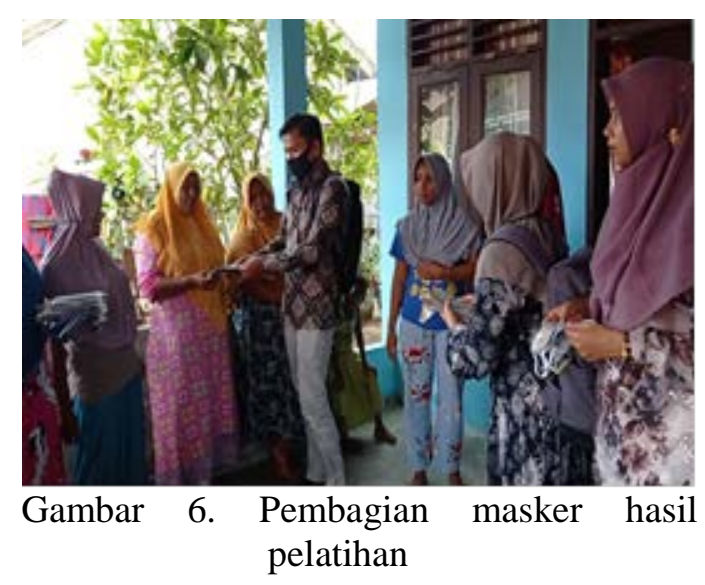

\section{KESIMPULAN}

Berdasarkan kegiatan yang telah dilakukan dapat disimpulkan bahwa kegiatan pengabdian ini sangat bermanfaat bagi masyarakat karena di situasi pandemic Covid-19 ini masyarakat sangat membutuhkan masker. Pembuatan masker, apalagi masker waterproof yang lebih baik perlindungannya dibandingkan masker kain biasa sangat menarik perhatian ibuibu sehingga mereka sangat bersemangat dalam melakukan kegiatan pelatihan. Para peserta memperoleh pengalaman baru dalam proses pembuatan masker sehingga dapat membuat sendiri masker untuk kegiatan luar sehari-harinya. Mereka menyadari pentingnya jenis masker yang digunakan dalam menentukan tingkat keamanan yang diberikan dari penyebaran virus sehingga bisa memilah masker yang lebih baik untuk digunakan.

\section{DAFTAR PUSTAKA}

Handayani, D. Hadi, D.R., Isbaniah, F., Burhan, E., Agustin, H. (2020). Penyakit Virus Corona 2019. Jurnal Respirologi Indonesia Vol 40 No 2 April 2020 Hal 119-129.

Mona, N, (2020), Konsep Isolasi dalam Jaringan Sosial untuk Meminimalisasi Efek Contagious (Kasus Penyebaran Virus Corona di Indonesia), Jurnal Sosial Humaniora Terapan Vol. 1 No. 22020 hal 117-124

Nugroho, M.I., Sugondo, P. Isworo, A., (2020). Literature Review: Transmisi Covid-19 dari Manusia ke Manusia di Asia, Jurnal of Bionursing Vol 2 No 2 Hal 101-112

Susilo, A. , Rumende, C.M., Pitoyo, C.W., Santoso, W.D., Herikurniawan, Sinto, R., Singh, G., Nainggolan, L., Yulianti, M., Nelwan, E.J., Khie , L., Chen, Widhani, A., Wijaya, E., Wicaksana, B., Maksum, M., Annisa, F., Chyntia, Jasirwan, OM, Yunihastut, E., (2020), Coronavirus Disease 2019: Tinjauan Literatur Terkini, Jurnal Penyakit dalam Indonesia Vol 7 No 1 Maret 2020. 